\title{
SILÊNCIO TAMBÉM É AXÉ
}

Iyaromi Feitosa Ahualli ${ }^{1}$

A vivência em um terreiro de Candomblé é composta por detalhes minuciosos. Quase tudo que se fala, que se faz, está dentro da estrutura ritualística deste universo de conhecimento. A passagem de conhecimento pela oralidade é o vetor que comentarei a seguir. E dentro da invocação de tantas palavras, o silêncio, as palavras não ditas, também é parte importante e necessária neste processo de aprendizagem e "vivência no axé".

O Candomblé, enquanto categoria principal de referência a religiões afroameríndias pelas terras da Bahia, - e que em seu processo de expansão chegou também a outros estados - carrega em si uma composição de diversas nações ${ }^{2}$ que podem ser lidas enquanto práticas específicas do culto à ancestralidade, à natureza, etc. Este pequeno texto, a priori, tinha o objetivo de marcar a composição das diferenças e semelhanças entre as nações de Angola e Ketu. Nações com grande força na formação do imaginário do culto do Candomblé.

Neste momento, devo me contextualizar em ambiente de "axé" enquanto uma pesquisadora nascida e criada em um terreiro de candomblé. Minha presença escrita no texto não poderia apenas pairar na produção deste material. Nasci na nação Ketu, por uma Iyalorixá nascida na nação Angola. Como isso é possível?

Com o objetivo de uma análise comparativa destas duas nações, busquei uma interlocutora que tenha transitado intimamente por ambos os cultos para uma entrevista. A entrevista foi feita com a Iyalorixá Lídia de Oxum (minha mãe de santo) e, para introduzir os caminhos tomados por esse texto, localizo seu lugar de fala.

Dona Lídia nasceu na nação Angola em meados de 1970. Após ter aberto um terreiro onde era cultuada a nação de Angola, houve acontecimento decisivo para que sua trajetória mudasse o rumo de Angola para Ketu. A solução de Iyá Lídia para com essa situação foi abandonar a casa em que nasceu e procurar na Bahia uma casa em que pudesse continuar a desenvolver sua missão espiritual. Em Salvador, tornou-se

\footnotetext{
${ }^{1}$ Graduanda em antropologia pela Universidade de Brasília (UnB) e graduanda em direito pelo Centro Universitário de Brasília (Uniceub). Iniciada do Candomblé de nação Ketu. Integrante do Calundu Grupo de Estudos sobre Religiões Afro-Brasileiras.

2 O termo "nações" está sendo usado como nação religiosa, conforme é comumente referido pelo povo de santo.
} 
integrante da família de santo Pilão de Prata, uma casa de candomblé Ketu. Alguns rituais foram feitos nessa nova casa e Dona Lídia continuou sua caminhada na espiritualidade na nação Ketu.

Este breve resgate não abarca toda a complexidade da mudança de nação, ou até mesmo o nascimento em uma delas. Mas se faz necessário para que a interlocutora seja apresentada.

O ambiente da entrevista era marcado por dois ipês amarelos, uma fonte, duas cadeiras e um gravador. Conversamos por horas sem perguntas necessariamente prontas sobre a complexidade do que aproxima e diferencia/distancia as nações de Angola e Ketu.

Após a entrevista e o diário de campo prontos, deixei que minha interlocutora lesse a composição da então conversa/entrevista. Este processo modificou completamente o foco deste trabalho. Foi na reflexão dela sobre suas palavras que me apoiei para escrevê-lo, além da complexidade das linhas que unem e separam essas nações, o silêncio sobre os segredos de ambas foi o que mais as aproximou.

Dona Lídia, ao ler o texto quase pronto, pediu para que eu retirasse grande parte das informações ali contidas com a seguinte explicação: “isso é segredo de axé”. A exposição da forma que compõe este material não é somente uma justificativa do formato do texto, estamos lidando com uma prática muito comum na estrutura do Candomblé que seria o culto ao segredo.

O que a Iyá Lídia nos deixou à mostra diz respeito à estrutura dos cultos; há que ressaltar que Orixá (nação Ketu) e Inquice (nação Angola) têm como base uma estrutura na qual os elementos da natureza são essenciais, sem natureza não se tem culto nem em Candomblé de Angola, nem em Candomblé de Ketu. Isso aproxima as nações, contudo, ainda que esse seja um ponto de contato, não estamos falando das mesmas forças. Segundo Iyá Lídia, “Orixá é a força da natureza, é a água, é a terra, é o ar, o vento, o fogo, a folha, os animais, assim como os Inquices. Mas os Orixás foram pessoas vivas, os Inquices são a própria natureza”. 


\section{Aquilo que nos une nos diferencia}

A mescla da natureza e da ancestralidade, mais exatamente da força cultuada, também diz respeito à composição da forma como é vivenciado o Candomblé em grande parte do território brasileiro. Do mesmo modo que se fala de Oxum como dona da água doce, também se fala de Dandalunda como a própria força da água. Apesar de ambas as forças serem cultuadas nos mesmos elementos naturais e compartilharem algumas semelhanças dentro do culto, não são a mesma força. Isso porque, mesmo tendo composições diferentes, o culto à ancestralidade e o culto aos inquices envolvem uma relação direta com a natureza.

Entre as diversas proximidades ditas em nossa conversa, a composição da natureza transmutada em um ancestral vivo aproxima o culto das nações. Há que se dizer que, mesmo em casas onde as sacerdotisas permaneceram em uma mesma nação, conceber a natureza como fonte essencial do culto é predominante no Candomblé. Inquices e Orixás coexistem juntos e separadamente. Juntos no espaço, no tempo, no rito. Mas cantados, cultuados e invocados diferentemente.

Apesar de a antropomorfização ser de importante destaque para a diferenciação entres os cultos de Angola e de Ketu, personificar a força que se cultua, mais exatamente a ancestralidade, não é uma característica unicamente da nação Ketu. Nesse aspecto, é importante dizer que o próprio culto a pessoas que foram iniciadas no culto aos Orixás/Inquices e depois morreram acontece em ambas as nações, ou seja, ancestrais diretos da casa são cultuados em ambos, Candomblé Ketu e Angola.

Dentro do silêncio ritualístico exigido por minha iyalorixá, podemos analisar que o fator que pode ligar ${ }^{3}$ ambas as nações de forma inteiramente igual é o ritual de passagem chamado axèxè. Este ritual é feito para as forças a quem esta pessoa foi consagrada em vida. A morte é o elemento/orixá que é cultuado de maneira única, independente da nação. Inclusive, neste ritual as diversas línguas faladas nos diversos cultos candomblecistas são cantadas.

Apesar dos elementos de destaque permitidos para análise da composição de uma e outra nação, não podemos pensar que elas se constituem somente em oposição. A concepção da própria categoria de Candomblé pressupõe uma solidariedade entre as

\footnotetext{
${ }^{3}$ Há aqui uma relativização, portanto, "pode ligar" não deve ser lido como "liga". O Candomblé é diverso e, ao passo que há casas que realizarão rituais de passagem sem diferenças entre nações, estas podem existir em outros terreiros. Ao tratarmos de Candomblé, jamais lidamos com absolutos.
} 
Revista Calundu - vol. 1, n.1, jan-jun 2017

nações, entre a comunidade do Candomblé como um todo. A simbologia do ritual de passagem é composta pela invocação das línguas predominantes dos diversos cultos presentes no Candomblé, a natureza como teia responsável por unificar todas as forças e a categoria do silêncio são elementos que compõem as particularidades de cada nação e a conexão entre elas.

Como dito anteriormente, este texto é mais contemplado pelo silêncio que cerca os fundamentos de ambas as nações do que pelo que se pode dizer sobre elas.

Aqui, trato o silêncio como ritual.

Candomblés não são religiões cujos cultos se estruturam a partir do ato de converter pessoas e/ou juntar um grande número de fiéis, por isso a argumentação para o convencimento por meio da palavra é desnecessária. Deste modo, o silêncio faz parte dos ritos nos cultos de Candomblé. O silêncio funciona como uma forma de manutenção da tradição ritualística e de proteção contra as pessoas externas a ela.

O silêncio tem diversas dimensões e penso sobre suas funções neste contexto específico.

Manter o silêncio, em relação a pessoas de "fora do terreiro" é uma forma de não permitir que as intimidades familiares de uma comunidade de terreiro sejam expostas e, de alguma forma, esta se torne mais vulnerável para a prática do racismo religioso, ou seja, uma maneira de autopreservação de cada comunidade de terreiro.

O silêncio também tem um significado de crescimento espiritual para quem tem como tradição a palavra oral, então a dimensão de escutar a si e ao Orixá/Inquice, que é parte da própria pessoa, é um movimento para dentro de si, do autoconhecimento e do caminho proposto pelos Orixás/Inquices.

É na força do silêncio sobre os fundamentos rituais fechados para participantes das casas que moram as diferenças entre cada nação. E é na aceitação deste silêncio, como aspecto que só interessa ser compartilhado com quem já é iniciado no culto Candomblé, que mora a característica de sonoridade entre as nações perante as pessoas de fora dela.

\section{Bibliografia}

SOUSA JÚNIOR, Vilson Caetano de. Nagô: a nação de ancestrais itinerantes. Salvador: Editora FIB Centro Universitário, 2005. 
Revista Calundu - vol. 1, n.1, jan-jun 2017

MELO, Emerson. "Dos terreiros de candomblé à natureza afro-religiosa". In Último andar: cadernos de pesquisa em ciências da religião n. 16. Programa de Estudos PósGraduados em Ciências da Religião, PUC-SP. São Paulo: EDUC, 2007: 27-36. 